\title{
Gelişen Teknolojiler, Değişen İşgücü Nitelikleri ve Eğitim
}

\author{
DOI: $10.26466 / o p u s .404223$
}

\section{$\underline{\text { Halil Buyruk }^{*}}$}

\author{
*Dr. Ankara Üniversitesi, Eğitim Bilimleri Fakültesi, Çankaya-Ankara/ Türkiye \\ E-Posta: hbuyruk@ankara.edu.tr \\ ORCID: 0000-0003-4817-3798
}

\section{Öz}

Son yillarda gerek ulusal gerekse uluslararası alanda eğitimin ekonominin gereksinimleri doğrultusunda yeniden yapılandırllması gerektiği öne sürülmekte ve bunu yerine getirmek için uluslararası örgütlerin öncülü̈ğ̈̈nde küresel boyutta düzenlemeler yapılmaktadır. Üretim için gerekli nitelikli işgücünün yetiştirilmesinde işlev görerek eğitimin ekonomide rol oynamasının tarihi Sanayi Devrimi'ne kadar uzanır. 19. yüzyılda sanayileşmenin hızlanmasıyla birlikte eğitimden beklenen işlev ile son yillarda teknolojinin gelişmesiyle birlikte değişen işgücü niteliklerini sağlamak üzere eğitimden beklenen işlev arasında bir paralellik söz konusudur. Ancak, günümüzde bu işlev daha merkezi bir konumda bulunmakta, eğitimin tamamıyla ekonomiye göre şekillenmesine yönelik politikalara küresel düzeyde hız verilmektedir. Yaşanan değişim gelişen teknolojinin bir gereği olarak tanımlanırken, yeni teknolojilerin yeni nitelikler gerektirmesi dolayısıyla eğitimin bu nitelikleri sağlamasının önemine işaret edilmektedir. Akıll fabrikalar, nesnelerin interneti, siber fiziksel sistemler gibi kavramlarla tanımlanan yeni bir endüstri devriminin yaşandığı öne sürülmektedir. Bu devrimle bir yandan işin, işgücü niteliklerinin, üretim örgütlenmesinin değişeceği, diğger yandan eğitimin bu eksende dönüşmesi gerektiği iddia edilmektedir. Bu çalışmada öncelikle teknolojinin ve üretim örgütlenmelerinin tarihsel gelişimi ana hatlarıla ele alınacak, sonrasinda ise yaşanan değişime paralel işgücü niteliklerinde ortaya çıkan değişimler vasıf ve istihdam kavramları etrafında tarihsel bir yaklaşımla tartışmaya açılacaktır. Son olarak, eğitimin yeniden yapılanması yapılan tartışmalar bağlamında ele alınarak eğitime yüklenen işlevdeki değişimler bilgi ekonomisi ve yaşam boyu öğrenme kavramsallaştırmaları ekseninde değerlendirilecektir. Böylece gelişen teknolojiler, değiş̧en işgücü niteliği ve eğitim arasındaki ilişkiler tarihsel ve kuramsal olarak çözümlenmeye çalışılacaktır.

Anahtar Kelimeler: Teknoloji, İsgücü, Vasıf, Üretim örgütlenmesi, Eğitim 


\title{
Developing Technologies, Changing Labour Qualities and Education
}

\begin{abstract}
In recent years, it has been suggested that the education should be restructured in line with the requirements of the economy both national and international level and in order to do this, regulations are made at the global level under the leadership of international organizations. The history of education's role in economy by functioning in the training of qualified workforce necessary for the production goes back to the industrial revolution. There is a parallelism between the function expected from education with the acceleration of industrialization in the nineteenth century and the function expected from education to provide changing workforce qualities with the development of technology in recent years. Today, however, this function has a more centralized position and the educational policies shaped entirely by the economy are being accelerated. While existing change is defined as a requirement of developing technology, it is pointed out that providing these qualities by education is important because new technologies require new qualifications. It is argued that a new industrial revolution has been experienced, defined by the concepts such as smart factories, internet of things, cyber-physical systems. With this revolution, it is claimed that on the one hand, the nature of work, the quality of the workforce, the organization of production will change on the other hand education must be transformed into this axis. This study first examines the historical development of technology and production organizations, and then it discusses the changes in labour qualities in parallel with the experienced changes by a historical approach around the concepts of skill and employment. Finally, it deals with the reconstruction of education in the context of previous discussions and evaluates the changes in the functions of education on the basis of knowledge economy and lifelong learning conceptualizations. Thus, it analyses the relationship between developing technologies, changing labour qualities and education historically and theoretically.
\end{abstract}

Keywords: Technology, Labour, Skill, Production organization, Education 


\section{Giriş}

Son zamanlarda kimi okullar, gazetelere verdikleri ilanlarda eğitim sistemlerini "Endüstri 4.0" modeline uygun olarak biçimlendirdiklerini, bu nedenle okullarından mezun olan öğrencilerin çalışma yaşamına daha avantajlı başlayacaklarını öne sürmektedir. Kodlama, finansal okuryazarlık, elektronik tasarım, STEM gibi dersler ise Endüstri 4.0'a yönelik eğitim programları arasında sayılmaktadır. Her ne kadar günümüzde çok fazla yaygınlaşmamış olsa da, bu ilanların kısa bir zaman sonra gazetelerin ya da web sayfalarının ilan bölümlerini süsleyeceğini söylemek mümkündür. Zira hızla gelişen teknolojiye paralel işgücü niteliklerinin değiştiği vurgusuyla yeni teknolojilere uyum sağlayacak, yeni niteliklerle donanmış işgücünün yetiştirilmesi ulusal ve uluslararası kuruluşlarca çokça dile getirilmektedir.

Eğitim ve üretim ilişkisinin tarihinin Sanayi Devrimi'ne kadar uzandığını söylemek mümkündür. Sanayileşmeyle birlikte kitlesel üretimin artması yeni kurulan fabrika düzenine uygun biçimde çalışacak işgücü talebi yaratmıştır. Daha önce atölye ya da ev tarzı çalışma alışkanlıklarına sahip ya da tarımsal üretimden gelen işgücünün fabrika düzenini, disiplinini, kurallarını öğrenmesi bir gereklilik olarak ortaya çıkmıştır (Bowles ve Gintis, 1976). Bu gereksinim nedeniyle bir yandan fabrikalar okullaşırken, diğer yandan eğitim kitleselleşmeye başlamış, okulların kurulması ve yaygınlaşmasıyla eğitimde kurumsallaşma yaşanmıştır (Rury, 2002). Sanayileşmenin hızla yaygınlaşması, Fordist üretim örgütlenmesinin geliştirilmesi üretimde ihtiyaç duyulan işgücü niteliklerinde çeşitli değişimler yaşanmasını beraberinde getirmiştir. Kafa ve kol emeği arasındaki ayrım keskinleşirken, artan hesap kitap işlerini yapacak eğitimli bir kitleye olan ihtiyaç artmıştır (Giddens, 2008). Artan bu ihtiyacı karşılamak üzere ilkokul üstü eğitimde kitleselleşme yaşanmaya başlamiş, daha önce eğitime erişemeyen toplumun geniş kesimlerinin bu eğitimden yararlanması mümkün olmuştur. Eğitimin kitleselleşmesinin ikinci aşaması olarak tanımlayabileceğimiz bu dönemde farklı toplumsal kesimlerin eğitimden yararlanmasına yönelik politikalara hız verildiği 
söylenebilir. Keynesyen ekonomi politikalarının ${ }^{1}$ uygulandığı II. Dünya savaşı sonrası dönemde yaşanan gelişmelerle eğitimin bir hak olarak görülmesine ve insanın gelişiminde oynayabileceği rol dolayısıyla tüm toplumsal kesimlerin erişimine açılmasına yönelik politikalara hız verilmiştir. Kuşkusuz eğitimin kitleselleşmesinin tek nedeni endüstrinin gereksinim duyduğu işgücü niteliklerini kazandırmak değildir. Eğitim, ulus devlet yapılanmasına paralel kültürel birliği sağlamada, yurttaş yetiştirmede önemli bir işlev görmüştür (Green, 1990). Ancak eğitimin önemli ölçüde, gelişen sanayileşmeye ve teknolojiye paralel gereksinim duyulan işgücü niteliklerini sağlayacak biçimde bir gelişim çizgisi izlediği söylenebilir.

1970'li yıllarda kapitalizmin içine girdiği krizden çıkma çabaları diğer tüm toplumsal alanlarda olduğu gibi eğitim alanında da bir dizi dönüşümün yaşanmasını beraberinde getirmiştir. Gelişen teknolojiye paralel üretim örgütlenmesi dönüştürülürken, işgücü nitelikleri yeniden biçimlenmiştir. Eğitimden bir yandan yeni ekonomiye uygun işgücünü yetiştirmesi beklenirken, diğer yandan "bilgi ekonomisi" yaklaşımından hareketle üretim için gerekli bilgi ve teknolojiyi karşılaması istenmiştir. Son yıllarda "dijital ekonomiye" geçildiğine ilişkin vurgular artmakta ve yeni bir endüstri devriminin yaşandığ 1 ileri sürülmektedir. Akıllı fabrikalar, nesnelerin interneti, siber fiziksel sistemler gibi kavramlarla tanımlanan yeni endüstri devriminin bir yandan işi, işgücü niteliklerini, üretim örgütlenmesini değiştireceği, diğer yandan eğitimin bu eksende dönüşmesi gerektiği iddia edilmektedir. Bu çalışmada gelişen teknoloji ve değişen üretim örgütlenmesine paralel dönüşen işgücü nitelikleri ve eğitimden beklentiler ele alınacaktır. İlk olarak, teknoloji ve üretim örgütlenmesinin tarihsel gelişimine odaklanılacak, sonrasında ise yaşanan değişime paralel işgücü niteliklerinde ortaya çıkan değişimler vasıf ve istihdam kavramları ekseninde tartışmaya açılacaktır. Son olarak, eğitimin yeniden

${ }^{1}$ Keynesyen ekonomi politikaları, 1929 yılında başlayan ekonomik krize çözüm olarak gündeme gelmiş, II. Dünya savaşı sonrası, özellikle gelişmiş ülkelerde "refah devleti" modelinin gelişiminde önemli bir rol oynamıştır. Uygulanan ekonomi politikalarının Keynesyen olarak adlandırılması, bu politikaların Keynes'in 1936'da yayınlanan "Istihdamın, Faizin ve Paranın Genel Teorisi" adlı kitabından yola çıkılarak oluşturulmasıyla ilişkilidir. Kapitalist sistemin piyasa kanunlarının işlemesiyle dengeye geleceğini iddia eden Neo-klasik iktisadı reddeden Keynes (2008), devletin ekonomiye etkili müdahalesini savunur. 
yapılanması yapılan tartışmalar bağlamında ele alınarak eğitime yüklenen işlevdeki değişimler bilgi ekonomisi ve yaşam boyu öğrenme kavramsallaştırmaları ekseninde değerlendirilecektir. Böylece gelişen teknolojiler, değişen işgücü niteliği ve eğitim arasındaki ilişkiler tarihsel ve kuramsal olarak çözümlenmeye çalışılacaktır.

\section{Teknoloji ve Üretim Örgütlenmesi: Tarihsel Bağlam}

Teknolojinin tarihini eski çağlara dayandırmak mümkünse de, egemenliğini ilan ettiği Sanayi Devrimi ile başlatmak, gelişen üretim teknolojileri bağlamında ele almak uygun olacaktır. Zira sanayileşme öncesi toplumlarda teknolojinin değiştirici gücü olmakla birlikte üretim ilişkilerini minimum düzeyde etkilediği söylenebilir. Oysa 18. yüzyılın sonlarından itibaren geliştirilen teknolojiyle gerek üretim alanında gerekse toplumsal yaşamda pek çok değişim yaşanmıştır. Buhar teknolojisinin kullanılmasıyla başlayan büyük dönüşümle birlikte insanın doğa ile ilişkisi değişmeye başlamış, insan doğayı bir hammadde olarak görmüş, doğadan alınan hammadde; makineler, enerji ve emek gücü kullanılarak yapılan işlem sonucunda doğada bulunmayan yeni bir ürüne dönüştürülmüştür (Aksoy, 2017, s. 36). Daha sonra teknoloji tarihine ilişkin çalışmalarda Sanayi Devrimi ya da Endüstri 1.0 olarak adlandırılan bu dönüşüm sürecinde üretim alanında makinalar kullanılmaya başlamış, daha önce evlerde ya da atölyelerde gerçekleştirilen üretimler fabrika çatısı altında birleştirilmiş, üretim artmış ve üretim artışına paralel ekonomik büyüme gerçekleşmiştir. Endüstri 1.0 kullanılan teknoloji ve üretim örgütlenmesi bakımından daha önceki üretim biçimlerinden köklü bir kopuş sağlamıştir.

Teknolojinin yanı sıra, üretimin nasıl örgütlendiği, iş bölümünün nasıl yapıldığı, teknolojik aletlerin, makinelerin nasıl konumlandırıldığı, böylece çalışanların verimliliğini nasıl etkilediği üretim üzerinde belirleyici olan diğer etkenlerdir. Zira Dickson'un (1992) vurguladığı gibi, teknoloji yalnızca bir toplum tarafından kullanılan alet ve makinalar değil, bunların kullanımları sonucu gerçekleşen ilişkileri de kapsar. Örneğin, "bilimsel yönetim" adıyla anılan Taylorizm, üretim sürecinin çeşitli işlem birimlerine bölünebilmesi için ayrıntılı bir şekilde incelemesine dayanan, üretimi artırmak amacıyla tasarlanan bir üretim örgütlenmesidir. 
Taylorizmin öncü uygulamaları manifaktür ${ }^{2}$ üretimde görülmekle birlikte, 20. yüzyılın başında Taylor'un çalışmalarını üretkenlik artışı sağlayacak şekilde yoğunlaştırması ile ortaya çıkmıştır. Taylorizmin en temel üç ilkesinden biri, emek sürecinin uzmanlıklardan kurtarılması ve basitleştirilmesi, dolayısıyla üretim sürecinin parçalanması; ikincisi, düşünme sürecinin üretimden çekilmesi yani planlamanın merkezi düzeyde gerçekleştirilmesi, böylece planlama ve uygulamanın ayrıştırılması; üçüncüsü ise, ikinci ilkeyi tamamlar nitelikte işçinin yapacağı her aşamanın yönetimce planlanarak işçiye direktifler halinde verilmesidir. Taylor (2011, s. 40), iş̧̧inin planlama faaliyetlerini daha önce kişisel tecrübesine dayanarak gerçekleştirdiğini, yeni sistemde ise bu görevin bilimsel kurallara uygun olarak yönetim tarafından gerçekleştirileceğini öne sürmüştür. Zira ona göre işçinin üretimin bilimsel tarafını geliştirebilmesi olanak dâhilinde değildir. İşçi yalnızca kendisine verilen talimatları yerine getirecek, işin diğer süreçleriyle ilgilenmeyecektir. İnsanların doğası gereği tembel olduğunu düşünen Taylor'a (2011) göre, herhangi bir kararın işçilere bırakılması yönetimin kendisini sınırlaması ve engellemesi anlamina gelecektir.

Taylorizm'den uzak bir örgütlenme biçimi olmayan Fordizm, Henry Ford tarafından 1900'lü yılların başında geliştirilmiş ve ilk kez Ford otomobil fabrikasında uygulanmış bir üretim örgütlenmesidir. Taylorizm'de emek sürecinin denetim altına alınması, çalışanların üretim süresince yaptığ 1 hareketlerin sistematik hale getirilmesi, verimliliğin ve dolayısıyla üretim kapasitesinin artırılması hedeflenmiştir. Fordizm, işçileri vasıfsızlaştırarak yönetimin işçilerin niteliklerine olan bağımlılığını ortadan kaldıran bir dizi adımın mekanize olmuş biçimidir (Ansal, 1996a). Fordist üretim örgütlenmesinde işler küçük parçalara bölünmekte, yapılış sırasına göre bir hatta dizilmekte, işçilerin üretim sırasında işi gereği parça almak ya da alet kullanmak için hareket etmeleri önlenmektedir. Bunun yerine işin nesnesinin üretim sürecinin gerektirdiği işlem sırasına göre dizilmiş makinalar ve iş istasyonları boyunca hareket etmesi sağlanmakta, böylece Fordist montaj hattı ortaya çıkmaktadır (Ansal,

\footnotetext{
${ }^{2}$ Manifaktür, sanayi devriminin hemen öncesinde ve başlangıcında belirli sayıda zanaatkârı aynı çatı altında toplayan, makine gücü kullanılmakla birlikte büyük ölçüde el emeği ile sürdürülen üretim faaliyetini ve bu üretim faaliyetinin geçerli olduğu dönemi ifade eder.
} 
1996a, s. 10). Başka bir ifadeyle, üretim sürecinin tüm aşamaları bir planlama dâhilinde sistematik olarak alt bölümlere ayrılmakta ve her bölümde çalışan işçinin görev tanımları belirlenmektedir. Dolayısıyla işgücünün katı bir işbölümüne tabi tutulmasıyla verimliliği en üst düzeye çıaracak biçimde zamanlama yapılarak, süreç en ince ayrıntısına kadar hesaplanmaktadır (Çakmak, 2004). Yeni makinaların üretim alanında kullanılması ve yeni bir üretim örgütlenmesinin devreye sokulması kitlesel bir üretime imkân tanımış, üretimi muazzam ölçüde artırmıştır. Kayan bant sistemine dayalı bu üretim örgütlenmesi ile yeni bir endüstri devriminin yapıldığı öne sürülmüştür. Endüstri 2.0 olarak adlandırılan bu dönemde Keynesyen ekonomi politikalarının da devreye girmesiyle kitlesel üretim ve kitlesel tüketim yaşanmıştır. Ancak 1970'li yıllara gelindiğinde petrol krizi ile başlayan, kar oranlarının düşmesi ve ekonomik büyümenin yavaşlaması gibi sorunlarla ortaya çıkan ekonomik kriz mevcut sistemin değişimine yönelik politikaların benimsenmesinde etkili olmuştur. Ekonomik, politik ve toplumsal boyutları kapsayacak biçimde yaşanan bu genel krizin bir parçası olarak Fordist üretim örgütlenmesinin krizi ise en genel anlamda "verimlilik düşmesi" ile açıklanmaktadır.

Üretimde verimliliğin düşmesi ve zaman kaybı olması üretim örgütlenmesinde değişime gidilmesi için öne sürülen temel sorunlardır. Önceki dönemlerle benzerlik gösteren bu sorunları aşmak için standart üretime dayalı katı bir organizasyona sahip Fordist üretim örgütlenmesinin yerine üretimin piyasadaki değişimlere hızla yanıt verebilecek biçimde esnek olduğu, girdi farklılaşmasına imkân tanıyabilecek şekilde değiştirilebilir bir teknolojinin kullanıldığ 1 Post-fordist olarak adlandırılan yeni bir üretim örgütlenmesine geçiş gündeme gelmiştir (Harvey, 1999; Amin, 2003; Kumar, 2004). Bilgi teknolojileri ile mikro elektronik teknolojilerin bir arada kullanılmasıyla oluşturulan programlanabilir makinaların üretime dâhil edilmesini ifade eden bu dönemde yeni bir endüstri devriminin yaşandığı öne sürülerek ileri teknolojiye dayalı gelişmeler Endüstri 3.0 olarak adlandırılmaktadır. Programlanabilir makinaların geliştirilmesiyle endüstriyel robotlar üretime sokulmuş, böylece üretim tüketici tercihlerine cevap verebilecek biçimde esnek bir yapıda örgütlenmeye başlamıştır (Yentürk, 1993). Esneklik üretim alanında bir değişimin yanı sıra üretimle ilişkili bütün yapılarda da değişime yol açmaktadır. Esneklik 
hem üretim aşamalarının parçalara ayrılması ve üretim alanında emeğin çok yönlü esneklikle donatılması anlamına gelirken, hem de yeni istihdam biçimlerini tanımlamak için kullanılmaktadır (Belek, 1997). Postfordist üretim örgütlenmesinde birbirlerinden farklı uygulamaları görmek mümkündür. Bunlardan birisi Piore ve Sabel (1984) tarafından dile getirilen esnek, genel amaçlı makineler kullanılarak vasıflı işçilerle çeşitli ürünlerin küçük ölçekli imalatını sağlayan esnek uzmanlaşmadır. Esnek teknolojinin esnek uzmanlaşmayı doğurduğunu ileri süren Kumar (2004, s. 61), yeni fikirlerin hızlı bir şekilde yeni ürünlere dönüşebildiğini belirtmekte ve üretimin müşteri talepleri doğrultusunda özgül isteklere göre, sürekli akış halindeki ihtiyaçlara uygun olarak şekillendiğini vurgulamaktadır. Bir diğer esnek üretim örgütlenmesi ise yalın üretim modelidir. Japonya'da ortaya çıkan ve daha çok büyük ölçekli işletmelerde kullanılan bu modelde, büyük ölçekli üretimden tamamen vazgeçilmezken, üretimin esnekleştirilmesinin önünde engel oluşturabilecek bölümler "alt sözleşme", "taşeronlaştırma" gibi uygulamalarla merkez üretimin dışına çıkarılmakta, küçük işletmelere devredilmektedir.

Son yıllarda yeni bir endüstri devrimi yaşandığından bahsedilmekte, internetin yaygınlaşması ve robotik teknolojilerin geliştirilmesiyle nesnelerin interneti tanımlaması üzerinden Endüstri 4.0'ın başladığı öne sürülmektedir. Bu dönem insan emeğinin üretimde kullanımının azalmasına, otomasyonun artışına işaret etmektedir. Endüstri 4.0, ilk olarak 2006 yılında ABD'de, daha sonra 2011 yılında Almanya'da Hannover Fuarı'nda dillendirilmiş, üretimde yeni bir paradigmanın başladığı öne sürülmüştür (Alçın, 2016). Teknolojik değişimler açısından ele alındığında diğer teknolojik gelişmeler gibi Endüstri 4.0'ın bir kopuşu ifade eden devrim mi yoksa evrimsel bir gelişme mi olduğuna ilişkin tartışmalar devam etmektedir. Endüstri 4.0, yapay zeka, üç boyutlu yazıcılar, robotik sistemler, nano teknoloji alanlarında yaşanan gelişmelerin sonucunda nesnelerin internet bağlantısı aracılığıyla diğer nesnelerle iletişime geçebileceği "akıllı" üretim dönemini ifade etmek için kullanılmaktadır (Aksoy, 2017). Endüstri 4.0, pek çok otomasyon sistemini, veri alışverişini ve üretim teknolojilerini içermektedir. Altyapıdan akıllı fabrikalara kadar çeşitli alanlarda çip ve sensörlerin kullanılabilmesiyle nesnelerin yapılacak iş ve işlemleri sağlayabilmesi değişen koşullara göre önlem alabilmeyi olanaklı kılmaktadır. Hiçbir insanın çalışmadığı fabrikalarda üre- 
tim yapılabilmekte, ürünler ve imalat makineleri radyo frekanslar arac1lığıyla haberleşebilmektedir.

\section{Teknoloji, Değişen İşgücü Niteliği ve İstihdam}

Teknolojinin ve değişen üretim örgütlenmelerinin işgücü niteliğine etkileri genel olarak vasıf tartışmaları ekseninde ele alınmaktadır. İşgücünde yaşanan değişimin vasıflanmayla mı yoksa vasıfsızlaşmayla mı sonuçlandığı bu tartışmaların eksenini oluşturmaktadır. Üretimin planlanmasından ürünün ortaya çıkarılmasına kadar olan sürecin bütünlüklü bilgisine sahip olmayı, bu bilgiyle uygulamayı birleştirebilmeyi ve iş üzerinde takdir yetkisi kullanabilmeyi ifade eden vasıf kavramı geleneksel anlamda daha çok zanaatkârlıkla birlikte anılagelmiştir.

Zanaata dayalı üretim düşünüldügünde, üretim becerileri uzun bir çıraklık dönemi sırasında öğrenilirken, zanaatkâr üretim sürecinin bütün aşamalarını başından sonuna kadar yerine getirmekte ve üretimin bilgisine sahip olmaktadır (Giddens, 2008, s. 793). Beceri ve ustalık gerektiren bu çalışma biçimi, aynı zamanda zanaatkârın kullanılan araçların bilgisine sahip olmasını da sağlamakta, böylece kafa ve kol emeği arasındaki ayrışma ortadan kalkmaktadır (Sayers, 2008, s. 53). Zanaatkâr hem üretim faaliyetinde bulunmakta hem de hammaddenin bulunmasindan satın alınmasına, çırak ve kalfaların yetiştirilmesinden, üretilen ürünlerin pazarlanmasına ve satılmasına kadar bütün süreçlerde yer almaktadır (Huberman, 2009, s. 127). Zanaatkârlık, halen çeşitli biçimlerde varlığını sürdürse de, teknolojinin gelişmesine paralel hızlanan sanayileşme sürecinde büyük oranda ortadan kalkmaya başlamış, yerini daha geniş bir üretim örgütlenmesi içinde yer alan işçiye bırakmıştır. Geleneksel üretimden küçük değişiklikler gösteren erken atölye tipi üretimde zanaatkâr geleneksel bilgi ve vasıflarını sürdürmüştür (Braverman, 2008, s. 83). Zanaatkârları aynı çatı altında toplayan manifaktür üretim formlarından biri, bağımsız zanaatlardan işçilerin bir atölyede, tek bir kapitalistin denetimi altında birleşmesi, diğeri ise aynı ya da benzer işleri yapan çok sayıda zanaatkârın bir araya toplanmasıdır (Marx, 2011, s. 327-328). Her iki formda da zanaatkârlığa dayanan üretim biçimi zamanla değişirken, teknik anlamda bir işbölümü gelişmiştir. İşbölümünün derinleşmesi ve işçilerin giderek daha fazla bir biçimde makinaların uzantılarına dönüş- 
meye başlamaları maddi ve zihinsel üretimi birbirinden koparırken, iş̧̧iler yaratıcı yeteneklerini kaybetmeye başlamış, aynı işi aynı biçimde yapar duruma gelmişlerdir. Otomasyon ve fabrikalaşmayla birlikte gelişen işbölümünü Marx şöyle tanımlamaktadır:

Gerçek manifaktür, geçmişte bağımsız olan işçiyi sermayenin komuta ve disiplini altına sokmakla kalmaz, aynı zamanda işçilerin kendi aralarında da hiyerarşik bir kademelenme yaratır. (...) işçinin bir yığın üretken içgüdü ve eğilimini baskı altında tutma yoluyla tek bir parça işteki hünerini seradaki gibi geliştirerek, onu bir hilkat garibesi haline sokar; tıpkı La Plata devletlerinde kürk veya yă̆ın almak için koca bir hayvanın boğazlanması gibi. Sadece özel parça işler farklı bireyler arasında dă̆̆lmakla kalmaz, bireyin kendisi de bölünür, bir parça işin otomatik motoru haline gelir... (Marx, 2011, s. 348)

Manifaktür üretim ve gelişen işbölümüyle birlikte emeğin bu yeni örgütleniş biçiminde daha önce üretimin tüm aşamalarını gerçekleştiren zanaatkâr, üretken yeteneğinden zamanla uzaklaşmış ve işin belirli bir parçasını gerçekleştirir hale gelmiştir (Buyruk, 2013). Dolayısıyla vasıflı bir çalışan olarak zanaatkâr, işin bütününün bilgisinden koparak bu özelliğini zamanla kaybetmeye başlamıştır.

Manifaktür dönemde çeşitli biçimlerde işbölümü gerçekleşmiş olsa $\mathrm{da}$, işçinin beceri ve kapasitesi üretimde önemli bir rol oynamakta, dolayısıyla işçinin el, ayak hareketleri ve hızı verimlilik artışını sınırlayabilmektedir (Aydoğanoğlu, 2011, s. 62). Bu nedenle üretim sürecinin yeniden örgütlenmesi, çalışanların üretim alanında yaptıkları hareketlerin verimliliği sağlayacak biçimde Taylorist yöntemlerle düzenlenmesi gerekli olmuştur. Taylor'ın geliştirdiği "bilimsel yönetim"den önce de yönetimin çalışanlar üzerinde bir denetiminden bahsetmek mümkündür. Ancak bu denetim çalışanın işi nasıl yapacağına müdahale etmezken, işin nasıl yapılacağına ilişkin bir düzenlemeyi içermektedir. Taylorizm'de ise planlama ve uygulama ayrıştırılmakta, işin nasıl yapılacağ 1 en küçük ayrıntısına kadar yönetim tarafından planlanmaktadır. Dolayısıyla Taylorizmin uygulanmasıyla birlikte iş̧̧i, her türlü beceriden, üretimin bilgisinden ve zihinsel faaliyetten koparılmakta ve vasıfsızlaşmaktadir (Ansal, 1996a).

Taylorizm'de iş en küçük ayrıntısına kadar planlanmasına ve standartlaştırılmasına rağmen, işçilerin makineler arasında gidip gelmeleri zaman kaybına ve verim düşüklüğüne yol açmıştır. Bu durumu engellemek için Fordist üretim örgütlenmesi devreye sokulmuş, makinelerin ve makinelerle birlikte işçilerin konumlanması yeniden düzenlenerek 
zaman kaybını minimum düzeye indiren bant sistemi ile verimlilik sağlanmıştır (Buyruk, 2013, s. 36). Böylece işbölümü derinleşirken, planlama ve uygulama arasındaki mesafe giderek daha fazla açılmıştır. Ansal'a (1996a) göre Fordizm, emek sürecinde yönetimin işçilerin becerilerine olan bağımlılığını ortadan kaldırarak onların vasıfsızlaşmasına yol açan bir dizi adımın mekanize olmuş halidir. Makineleşmenin artması, işin parçalara ayrılması ve planlama işinin yönetimde toplanması ile birlikte vasıfsız işçi sayısında önemli bir artış olmuştur. Ancak bütün işlerin vasıfsız olduğu söylenemez. Fordist dönemde üretim sürecindeki işlerin büyük bölümü vasıfsız işçiler tarafından yerine getirilmekle birlikte, vasıflı işgücünün ve vasıfsız işgücünün yaptığı işler olmak üzere sınırları kesin olarak belirlenmiş hiyerarşik kategorilere ayrılmıştır

Post-fordist üretim örgütlenmesiyle birlikte işgücünün niteliğinde yaşanan değişime ilişkin iki farklı yaklaşımdan bahsedilebilir. Bunlardan ilki, gelişen teknolojinin, üretimde kullanılmaya başlanan bilgisayar ve otomasyon sistemlerinin işgücünün niteliğini artıracağına ilişkindir. Piore ve Sabel'e (1984) göre, üretimde bilgisayarlaşma üretenin kullanım kapasitesini geliştirecek, makineyi yeniden kullananın emrine verecek, böylece emek sürecinde yeniden denetim kurmasını sağlayacaktır. Zanaatkârlık dönemine özgü kafa ve kol emeğinin bütünleşmiş yapısı ve üretimin bütünlüklü durumunun bilgisayarlı üretime geçişle birlikte yeniden ortaya çıktığını ileri süren Piore ve Sabel (1984), yaşanan dönüşümü Taylorist işbölümünden zanaatçlığa geçiş olarak yorumlamışlardır. Oldukça iyimser olan bu yaklaşıma benzer biçimde Bell (1999), işgücünün geçmişe kıyasla eğitimli bir kitleden oluşacağını, mavi yakalılardan beyaz yakalılara doğru geçiş olacağını ve dolayısıyla profesyonel mesleklerde bir yoğunlaşma yaşanacağını ileri sürmüştür. Drucker (1993) da benzer biçimde bilginin artan önemine dikkat çekmiş, oluşan yeni işgücünü bilgi ya da hizmet iş̧̧ileri olarak tanımlamıştır. Toffler (2008), elle imalatın yerini zihinle imalata bıraktığını öne sürmüş, eğitimin giderek artan önemine vurgu yapmıştır. Toffler'e (2008) göre, eğitimli yeni işgücü hem daha fazla pazarlık gücüne sahip olacak hem de işletmenin gözünde feda edilemez bir konumda olacaktır. Dolayısıyla sanayi işçisinden farklı olarak teknolojik gelişmeyle birlikte ortaya çıkan bilgi işçileri güçlü bir konuma sahip olacaktır. 
Diğer yaklaşım ise sanayi sonrası toplum savunucularının tezlerine bir yanıt olarak görülebilecek, Braverman'ın (2008) temsil ettiği, yalnızca sanayi işlerinin değil, büro işlerinin de imalat sanayilerinde olduğu gibi Taylorizasyona uğrayabileceği, böylece çalışanların vasıfsızlaşacağına ilişkindir. Bu yaklaşıma göre, beyaz yakalıların işleri de aynı mavi yakalılar gibi rutinleşmeye, parçalanmaya ve vasıfsızlaşmaya tabi olabilir. Dolayısıyla Braverman'ın yaklaşımına göre, hizmet sektörünün ekonomideki payı arttıkça profesyonelleşme yaşanacağına ilişkin tez doğru değildir. Bilim ve teknoloji ilerledikçe vasıfsızlaşmanın artacağını belirten Braverman (2008, s. 386), bilimin emek sürecine daha fazla eklemlenmesiyle işçinin bu süreç hakkında daha az şey kavrayacağını, makineler karmaşıklaştıkça işçinin makine üzerindeki kontrolünün de azalacağını ileri sürer. Daha az vasıflı, dolayısıyla daha az maliyetli personelin kullanılması, iş hızının ve iş için gerekli becerilerin kontrol edilmesi üretkenliği arttırmak için önemlidir. Daha az vasıflı işgücünün kullanılabilmesi ise teknolojinin gelişmiş olmasını gerektirmektedir. İşlerin vasıfsızlaştırılmasıyla, daha önce iş üzerinde kontrol sağlayan işçi de zaman içinde vasıf gerektirmeyen işin gerekleri doğrultusunda vasıflarını kaybederek işin kontrolünü ve planlamayı başka birilerine, yani yönetime devretmiş olur (Apple, 2006, s. 186). Teknolojinin vasıf üzerinde yarattığ1 etkiyi Marx'ın İngiltere'deki kitap basma işinden verdiği örnek üzerinde rahatlıkla görmek mümkündür. Marx (2011, s. 463), eskiden kitap basımı işinde manifaktür ve zanaatçılığa uygun bir sistem içerisinde, çırağın, zamanla basit işlerden başlayarak daha karmaşık işlere geçtiğini ve bir matbaa ustası oluncaya kadar bir öğrenme süreci yaşadığını, okuyup yazabilmenin de bu iş kolunda çalışan her çocuk için zanaatın bir gereği olduğunu vurgular. Ancak baskı makinesinin ortaya çıkmasıyla birlikte tüm süreç değişmiştir:

Makine ile birlikte bu işyerinde iki tür işçi çalıştırılmaya başlandı: yetişkin işçiler ve genç işçiler. Yetişkinlerin işi makinelerin işlemesini gözlemekti; çoğunlukla 11-17 yaşları arasında olan genç işçilerin bütün yaptıkları [ise], kâğıt tabakalarını makinenin altına yaymak ya da basılan kâğıtları makinenin altından çekmekten ibaretti (Marx, 2011, s. 463).

Sennett (2005, s. 70-78) de benzer biçimde bir fırındaki üretim süreci üzerinden gelişen teknolojiyle birlikte fırıncılıkta yaşanan vasıf kaybını ortaya koyar. Fırında faaliyete geçirilen teknoloji nedeniyle fırın işçileri ekmeğin nasıl yapıldığı bilgisinden zamanla uzaklaşmaktadır, çünkü 
esas olan ekmek yapan makinelerin nasıl kullanılacağıdır. Fırında yine ekmek üretilmektedir, ancak yapılan iş fırıncılık değildir. Çünkü üretim sürecinin bütünlüklü bilgisine sahip olmayan işçilerin bilgi ve becerileri fırında karşılaştıkları herhangi bir sorunu çözmek için yeterli gelmemektedir. Makineler bozulduğunda müdahale edemeyen işçiler aynı zamanda ekmek yapma becerilerine sahip olmadıkları için eski tarzda ekmek de yapamamaktadır (Buyruk, 2013).

Teknolojik gelişmelerle birlikte vasıfsızlaşma yaşanabilirken, aynı zamanda yeniden vasıflanma gerçekleşebilmektedir. Bu yaklaşım temelde kapitalist üretim biçiminde vasıflı çalışanların tamamının ortadan kalkmasının istenilen bir şey olmadığı tezine dayanmaktadır. Zira sermaye birikiminin sağlanabilmesi üretkenlik artışını sağlayacak vasıflı işgücü gerektirebilmektedir (Friedman, 1977). Yalın üretim modelini örnek gösteren Ansal (1996b), en azından çekirdek işçi düzeyinde üretim bilgisine sahip, işin bütününü kavramış, işiyle bütünleşmiş, emek sürecinde kısmi bir kontrole sahip, takdir yetkisini kullanabilen ve çok çeşitli işler yapabilen işçilerin yeniden vasıflandırılmış olduklarını söylemenin mümkün olduğunu belirtir. Dolayısıyla vasıfsızlaşma ya da yeniden vasıflanma sermaye birikim sürecinin gerekliliklerine bağlı olarak değişimler gösterebilir (Thompson ve Smith, 2009). Hem vasıfsızlaşmanın hem de yeniden vasıflanmanın aynı anda gerçekleşebileceğini belirten Huws (2006) teknik işbölümüne dayalı her yeni gelişmenin yeni bir bölünmeyi beraberinde getireceğini vurgulamaktadır. Bir grup işçinin işi rutinleşirken, genellikle daha küçük bir grubun işi sürecin bütününü kontrol edecek biçimde gelişmektedir. Apple'a (2006, s. 186) göre de vasıfsızlaş(tır)ma, karmaşık bir süreç olarak işlemekte ve yeniden vasıflandırma süreciyle birlikte gerçekleşmektedir. Çünkü değişen teknolojiyle birlikte gelişen her yeni işbölümü bir grup işçinin yeni vasıflar geliştirmesini gerektirirken, büyük oranda vasıfsız çalışanların sayısı artmaktadır. Hirsch (2011), teknoloji yoğun ve bazı kilit sektörlerde işgücünün yeniden vasıflandığını, üretim ve hizmetin standart olduğu alanlarda ise vasıfsızlaşmanın yoğunlaştığını belirtmektedir. Dolayısıyla büyük bir grup vasıfsızlaşırken, daha küçük bir grup yeniden vasıflanmaktadır. Böylece, bir yanda az sayıda vasıflı işgücünün diğer yanda çok sayıda vasıfsız işgücünün olduğu kutuplaşmış bir durum ortaya çıkmaktadır. 
Teknolojik gelişmelerin vasıf üzerindeki etkisine benzer biçimde, istihdam üzerinde de yoğun etkileri söz konusudur. Yeni teknolojiler ve istihdam ilişkisi üzerine temel olarak iki farklı görüşten bahsedilebilir. Çeşitli çalışmalarda farklı şekillerde adlandırılmakla birlikte, ilk görüş yeni teknolojilerin istihdam üzerinde olumlu etki yaratacağı, kullanılan bilgi ve iletişim teknolojilerinin istihdamı artıracağı ve çalışma hayatının kalitesini geliştireceği yönündedir. Japonya gibi ileri teknoloji kullanan ülkelerde işsizlik oranının diğer ülkelere göre düşük olması bu görüşü destekleyen bir örnek olarak sunulmaktadır. Bu yaklaşıma göre, yeni teknolojilerin kullanılması değil, kullanılmaması işsizliğe neden olacaktır. Nitekim İngiltere ve diğer bazı ülkelerde görülen işsizliğin nedeni verimliliği ve rekabet gücünü artıran yeni teknolojilerin bu ülkelerde geri kalması çerçevesinde açıklanmaktadır. Bu yaklaşıma göre, yeni teknolojiler ilk etapta işsizliğe yol açsa dahi ortaya çıkacak verimlilik ve refah artışı yeni ürünler, yeni pazarlar, yeni endüstriler ve yeni istihdam olanaklarını beraberinde getirecektir (Alçın, 2010; Tokol, 2000). Neoklasik iktisat kuramıyla uyumlu olan bu yaklaşım, temel olarak teknolojinin yaratacağı işsizliğin geçici olduğu, başka sektörlerde yaratılan işlerle telafi edilebileceği anlayışına dayanmaktadır. Literatürde "telafi mekanizması" olarak adlandırılan yaklaşıma göre, teknolojik ilerlemenin emekten tasarruf etkisi piyasa odaklı dolaylı etkilerle sağlanan bazı mekanizmalar yoluyla telafi edilebilecektir. Dolayısıyla teknolojik değişimler uzun vadede yeni işlerin ortaya çıkmasını sağlayacaktır (Machin, 2003; Vivarelli and Pianta, 2000; Vivarelli, 2007).

İkinci yaklaşım, yeni teknolojilerin işsizliğe yol açacağı yönündedir. Bu görüşe göre, emeğin yerine makinanın ikame edilmesi işsizliği artıracaktır. İyimser yaklaşımda teknolojik gelişmelerin yüksek vasıflı işgücünün istihdamını artıracağı, diğer yandan vasıfsız işgücünün istihdam şansını azaltacağına ilişkin bir tespit söz konusudur. Dolayısıyla mevcut işgücünde bir değişim olması gerektiğinden hareketle işgücü vasıf kazandıkça istihdam şansının artacağı düşünülür. İleri teknolojinin kullanılmasının yüksek vasıflı bir işgücü gerektirmesi kaçınılmazdır ancak bu sayının az olması beklenmektedir. Dolayısıyla teknolojik değişim vasıflı emek ve vasıfsız emek arasındaki uçurumu açacak, istihdamda kutuplaşma yaratacaktır (Rifkin, 1995; Autor, Levy ve Murnane, 2003). Bu yaklaşıma göre, yarı-vasıflı işler makineler tarafından ikame edileceğinden 
yarı-vasıflı işçilerin rutin işleri yapması olası görünmektedir. Vasıf gerektirmeyen işler otomasyona uğramayacağı için, vasıfsız işçilerin rutin işlerine devam etmesi beklenmektedir. Dolayısıyla emek piyasasındaki kutuplaşma yarı-vasıflı işlerin ortadan kalkacağına işaret etmektedir.

Post-fordist üretim örgütlenmesinin gelişmesiyle birlikte işgücü piyasasında yeni istihdam biçimleri ortaya çıkmaya başlamış, işgücü niteliğinde değişimler yaşanmıştır. Bir tarafta beceri düzeyi yüksek ve bu çerçevede sürekli istihdam olanağı bulabilen bir çalışan kitlesinden bahsedilebilirken, diğer yanda beceri düzeyi düşük, zaman zaman iş bulabilen yedek bir işgücü ordusu oluşmuştur. İşgücü piyasasındaki bu bölünmeyi "ikili işgücü piyasası kuramı" ile açılamak mümkündür (Ünal, 1996). Kurama göre, ileri teknolojinin ve yeni tekniklerin kullanıldığ işletmenin merkezinde gelişmiş teknik becerilere sahip vasıflı bir işgücü daimi statüde çalıştırılırken, ikincil ya da dışsal emek piyasasında sürekli istihdam garantisi olmayan, gerektiğinde istihdam edilen standart dışı ve vasıfsız bir işgücü yer almaktadır. Ortaya çıkan bu kutuplaşmanın gelişen teknolojiye paralel artarak devam etmesi olası görünmektedir.

Son yıllarda mikro elektronik alanındaki gelişmelerin bir sonucu olarak ortaya çıan yeni otomasyonun istihdam azaltıcı bir etki göstermesi beklenmektedir. Zira pek çok standart işin robotlar tarafından yapılmaya başlamasıyla, çalışmanın bir bölümü insanlar tarafından yerine getirilmeyecektir. Artan rekabet koşullarında bilişim teknolojilerindeki ucuzlamaya paralel teknoloji kullanımının daha ekonomik olması yeni teknolojilerin kullanıldığı ülkelerde istihdam kaybı yaratabilmektedir. Bu nedenle, ileri teknolojinin istihdamı azaltacağ 1 ve kitlesel işsizlik yaratacağına dair tezler son dönemde yaygınlaşmıştır. Ancak teknolojik değişimlerin istihdamı azaltacağına ilişkin korkuların yeni olmadığını belirtmek gerekir. Sanayi Devrimi ile birlikte yeni makinelerin ortaya çıkmasına paralel işsizliğin artması beklenmiş, üretimde makinelerin kullanılmasıyla birlikte ilk etapta bir tepki olarak 18. yüzyılda makine kırıcılık hareketi ortaya çıkmıştır. 19. ve 20. yüzyıllarda da benzer kaygılar paylaşılmış, ancak sanayileşme ile birlikte istihdam tarım sektöründe azalırken sanayide artmıştır. Fakat dijitalleşme, robotların üretimde kullanılması, akıllı fabrikalar gibi son zamanlarda teknolojide meydana gelen değişimler benzer korkuların yeniden gündeme gelmesine yol açmıştır. Hizmet sektörünün sanayi sektöründe açığa çıkan işgücünü emmesi beklenmek- 
tedir. Hizmet sektörünün de otomasyondan korunamayacağını belirten Rifkin (1995) teknolojik gelişmelerin işsiz bir geleceği beraberinde getireceğini öne sürmektedir. Frey ve Osborne'a (2017) göre, Amerika Birleşik Devletleri'nde hizmet sektöründeki çeşitli işler (beyaz yakal1/muhasebe/lojistik/bilişsel görevler) dâhil olmak üzere mesleki kategorilerin \% 47'si otomasyona uğrama konusunda yüksek risk taşımaktadır. Yeni iş alanlarının açılacağına dair olumlu görüşler olsa da, bu sayının fazla olmayacağı tahmin edilmektedir. Dolayısıyla akıllı fabrikaların yaygınlaşmasına paralel kitlesel işsizliklerin yaşanması olası görünmektedir. Ancak istihdam sağlanması için nitelikli işgücüne ihtiyaç duyulduğu, bunun içinse eğitimin önemli olduğu küresel örgütler tarafından sık sık dile getirilmektedir. Dolayısıyla nitelikli işgücü yetiştirilmesinde eğitime biçilen rol pek değişmezken, özellikle son dönemlerde gelişen teknolojiye paralel eğitimin rolünün daha da arttığına ilişkin vurgu güçlenmiştir.

\section{Değişen Eğitim Paradigması}

Eğitime yüklenen, ekonominin gereksinim duyduğu işgücünü yetiştirme işlevinin temelleri Sanayi Devrimi'ne kadar uzanmakla birlikte, son dönemlerde küresel düzeyde yaşanan gelişmelerin bir sonucu olarak eğitim ve istihdam arasında çok daha sıkı bir bağ kurulmakta, hatta neredeyse eğitimin tek işlevinin yeni ekonominin gereksinim duyduğu işgücü niteliklerini sağlamak olduğuna ilişkin vurgular artmaktadır ${ }^{3}$. Kapitalizmin değişen koşullarına göre biçimlenen bu işlevin, küresel okuryazarlığı sağlamaktan küresel bilgisayar okuryazarlığını yaygınlaştırmaya doğru evrim geçirdiği söylenebilir. Yeni kapitalizmde eğitime yüklenen işlev, bilgi ekonomisi etrafında tartışılmakta, eğitimin bilgi ekonomisinin gerekleri doğrultusunda yeniden biçimlenmesi gerektiği öne sürülmektedir.

\footnotetext{
${ }^{3}$ Gerek OECD ve Dünya Bankası gibi uluslararası kuruluşların yayınladığı belgelerde gerekse ulusal düzeyde hazırlanan çeşitli raporlarda ve kalkınma planlarında eğitimin ekonominin gereksinimleri doğrultusunda şekillenmesi gerektiğine vurgu yapılmaktadır. Bu konuda bazı yayınlar için bkz. World Bank, 2005; DPT, 2006; TüSiAD, 2006; Kalkınma Bakanlığı, 2013; OECD, 2013, 2015.
} 
Bilgi ve iletişim teknolojilerindeki gelişmelere paralel olarak gerek toplumsal yapıda gerekse ekonomide bilginin öneminin arttığı vurgulanarak, daha önceki toplumsal yapılardan ya da ekonomik yapılanmalardan farklılığı ortaya koymak amaciyla "bilgi toplumu" ya da "bilgi ekonomisi" kavramsallaştırmaları kullanılmaktadır. Son dönemlerde kimi zaman "dijital ekonomi" gibi kavramlarla ikame edilerek de kullanılan "bilgi ekonomisi", bilginin bir değer yaratıcısı olduğuna ilişkin vurguyu içermektedir. Bilgi ekonomisi tanımlaması, bilgiye yüklenen işlev doğrultusunda "sanayi-sonrası toplum", "enformasyon toplumu", "postendüstriyel toplum" gibi teorik yaklaşımlar ekseninde biçimlenmiştir. Enformasyon toplumu kuramcılarına göre, yaptıkları işler uzun bir öğretim döneminden geçmeyi gerektiren, yüksek bir teknik vasıf düzeyi ve kuramsal bilgi tarafından belirlenmiş yeni bir bilgi işçileri hizmet sınıfı ortaya çıkacaktır (Kumar, 2004). Sanayi sonrası toplumu bir enformasyon toplumu olarak tanımlayan Bell'e (1999) göre, belirli bir gelişme çizgisi izleyen toplumlar sanayi toplumundan sanayi sonrası topluma geçmektedir. Teorisinde bilgi başat bir oynayan Bell (1999), üniversitenin ve eğitimin artan rolüne dikkat çeker. Bilgi ekonomisinde işgücünün büyük bölümünü profesyonel eğitimli bir kitle oluşturacağı için, eğitim önemli bir rol oynayacaktır. Post kapitalist toplum adlandırmasını kullanan ve sanayi toplumunda geçerli olan üretim araçlarının değiştiğine dikkat çeken Drucker (1994), bilginin yeni üretim aracı olduğunu belirtir. Bu çerçevede bu sürecin temel aktörü olarak bilgi işçisini ön plana çıkarır ve gücün kapitalistten bilgi işçisine geçeceğini iddia eder. Bell'e (1999) benzer biçimde işgücünün önemli bir kesimini eğitimli bilgi işçilerinin oluşturacağını düşünen Drucker'a (1994) göre, eğitim bilgi işçilerinin yetiştirilmesinde kritik rol oynayacaktır. Yaşanan toplumsal değişimleri "dalgalar" olarak adlandıran Toffler'a (2008) göre, son yaşanan değişim üçüncü dalgadır. Toffler de (2008) diğer teorisyenlere benzer biçimde bilginin artan önemi dolayısıyla eğitimin yeni kapitalizmde önemli bir rolü olduğuna vurgu yapmıştır. Zira eğitimli yeni işgücü sahip olduğu bilgi ve aldığı eğitim dolayısıyla daha fazla pazarlık gücüne sahip olacak, böylece işletme için feda edilemez bir konuma sahip olacaktır.

Yeni kapitalist paradigma çerçevesinde eğitime toplumsal hareketliliği sağlama açısından da önemli bir işlev yüklenir. Kapitalizmin yeni bir aşamasında olduğumuzu öne süren bu yaklaşıma göre, insanlar eğitime 
yatırım yaparlar ve böylece toplumsal hiyerarşide yukarı doğru tırmanma fırsatı elde ederlerse, yaratıcllığın önemli olduğu yüksek ücretli, iyi konumlu işlere erişebilirler (Lauder vd., 2012). Yukarı doğru toplumsal hareketliliğin sağlanabilmesi için devletin bütün vatandaşlarına eğitim fırsatı yaratacağı, bu ortamda bütün öğrencilerin yetenekleri ölçüsünde en iyiye ulaşmak için çaba harcayacağı varsayılmıştır. Dolayısıyla devlet bir yandan ekonomik rekabet sağlarken diğer yandan toplumsal adaleti sağlayacaktır. Ekonomik rekabetin kalbinde bilgi olduğu kabul edildiğinden, iyi eğitimli vatandaşlara sahip devletlerin küresel ekonomide öne geçeceği varsayılmıştır. Bu varsayımın temelinde bilgi ekonomisinin artan bir şekilde yüksek ücretli bilgi işi yaratacağı vardır. Bütün toplumsal kökenlerden öğrenciler yüksek statülü bilgi işlerine talip olabileceği için yukarı doğru sosyal hareketlilik ve sosyal adalet mümkün olabilecektir. Bilgi ekonomisinde toplumsal adaletin artacağı ve dileyen herkesin mezun olduğunda bilgi temelli bir iş edinebileceği ve dolayısıyla eğitime yatırım yapabileceği varsayılmıştır.

Eğitim almanın ve öğrenmenin kazanç ve statü elde etmeye eşitlendiği bilgi ekonomisinde yüksek gelirli bir iş elde etmek için eğitime yatırım yapmak gerekir anlayışı hâkimdir. Dolayısıyla bu yaklaşımın kökenleri İnsan Sermayesi Kuramı'na (ISSK) dayanır. İSK'da eğitim için yapılan harcamalar yatırım olarak ele alınır ve bu yatırımın verimlilik ve kazanç farklılıklarının açıklanmasında kullanılabileceği öne sürülür (Schultz, 1961; Becker, 1964). 1960'lı yıllarda ortaya çıkan, ekonomik büyümenin işgücünün bilgi ve becerisine bağlı olduğunu ve dolayısıyla eğitime yatırım yapmakla mümkün olabileceğini ileri süren İSK, ilerleyen yıllarda popülerliğini kaybetse de, son yıllarda küresel aktörlerin etkin çabasıyla yenilenerek yeniden gündeme gelmiştir. Yeni İnsan Sermayesi Kuramı'nda bir önceki kuramda ileri sürülen iddia küresel ekonominin gereklilikleri doğrultusunda bireylerin, şirketlerin ve uluslararası düzeyde devletlerin rekabet üstünlüğünü kapsayacak şekilde genişletilmiştir (Rızvı ve Lingard, 2016, s. 95). Her ne kadar yeni kuramın sahip olduğu boyutların farklı olduğu iddia edilebilirse de, temelde serbest piyasada rekabet koşullarında ekonomik çıarları için hareket eden birey tasarımına dayanır. Rasyonel birey tanımlamasına dayanan bu yaklaşımda küresel bir ekonomide performansın insanların bilgi birikimlerine, beceri düzeylerine, öğrenme kapasitelerine ve kültürel uyumlarına giderek 
daha fazla bağlı olduğu öne sürülür. Bu nedenle yeni ekonominin gereksinim duyduğu işgücü esnekliğini artıran politikalara önem verilmekte ve tüm bu gereklilikleri karşılayacak biçimde eğitim sisteminde reformlara ihtiyaç olduğu vurgulanmaktadır. Bu çerçevede eğitim sistemlerinin yeniden düzenlenmesi ve eğitimin amaçlarının yeniden tanımlanmasına yönelik politikalara hız verilmektedir.

İSK'da öne sürüldüğü gibi, rasyonel bireyin yaşam boyu elde edeceği kazançlar için eğitime yatırım yapması bireysel bir tercihtir. Oysa işgücünde geliştirilmesi istenen vasıfların küreselleştirilmesi hedeflenmekte, bu ise eğitime yatırım yapılmasını gerektirmektedir. Fakat vasıflı işgücüne ihtiyacı olan işveren eğitim için büyük yatırımlar yapmaktan kaçınmakta ve bu görevi büyük oranda devlet üstlenmektedir. İSK'da dile getirilen, eğitime yatırım yapan birey büyük oranda kendisi yarar sağlamaktadır, bu nedenle "yararlanan öder" şeklinde formüle edilen ilke ile son yıllarda eğitimin maliyeti büyük oranda bireylere yıkılmaktadır. $\mathrm{Bu}$, bir yandan ihtiyaç duyulan işgücü niteliklerini bireylerin kendilerinin sağlaması anlamına gelirken, diğer yandan eğitimin özelleştirilmesi politikalarına kapı aralamıştır. Böylece eğitim sermaye için yeni bir yatırım alanı olmuştur.

Günümüzde formel eğitim süresinin artırılması ve alınan eğitimin içeriğinin küresel ekonominin gereklerine göre düzenlenmesi konusunda eğitim sistemleri üzerinde büyük bir baskı oluşturulmuştur. Ekonomi için eğitim anlayışının gelişiminde önemli roller oynayan $\mathrm{OECD}, \mathrm{AB}$, UNESCO, Dünya Bankası gibi uluslararası kuruluşlar eğitimle ilgili bilgilerin düzenlendiği merkezler haline gelmiştir ve eğitimde yapılan reformların küresel ekonominin gereksinimleri doğrultusunda gerçekleştiğine dair bir söylem geliştirmişlerdir (Rızvı ve Lingard, 2016, s. 94). Özellikle OECD'nin küresel düzeyde düzenlediği sınavlar yoluyla ekonomi için gerekli kimi niteliklerin ölçülmesinde ve geliştirilmesinde belirleyici bir konumda olduğu söylenebilir. Uluslararası düzeyde yapılan bu s1navlar, devletler arasındaki küresel rekabetin görüldüğü alanlardan biri olmuştur. Sınavlardan elde edilen bilgilerin ülkelerin gelecekteki ekonomisi hakkında bilgi verdiği varsayımı üzerinden hareket edilmekte ve performansa dayalı oluşturulan lig tabloları aracılığıyla devletler rakiplerinin sıralamasını görebilmektedir. Ancak bu sınavlar kültür, bilgi ve pedagojideki farklılıkları ve öznel koşulları çok fazla dikkate almaksızın, 
bunları teknik problemlere indirgemekte ve öğrenci başarılarını küresel düzeyde karşılaştırmaktadır (Lauder vd., 2012).

Değişen ekonomi-politik koşullara göre eğitim sistemlerinin küresel olarak düzenlenmesinde etkin bir rol oynayan ve teknolojik gelişmelerin etkileri konusunda oldukça iyimser bir yaklaşım ortaya koyan OECD'ye (1996) göre, bilgi ve iletişim teknolojilerindeki gelişmeler bilgi üretimi ve kullanımının doğasını, çalışma ilişkilerini, ticaret yöntemlerini, tüketim tercihlerini değiştirmektedir. Bu nedenle bu dönemde eğitim, bilgili, esnek, uyumlu, hareketli, küresel anlayışa sahip, kendine güvenen, yaşam boyu öğrenen, yaratıcı bireyler yetiştirmelidir. Eğitimin amaçlarını beşeri sermaye geliştirmek ve ekonominin gereksinimleri doğrultusunda değişen işgücü niteliklerini kazandırmak çerçevesinde tanımlamak ona araçsal bir işlev yüklemeyi beraberinde getirmektedir. Dolayısıyla eğitimin amaçları daha fazla bir biçimde ekonomik gereksinimler çerçevesinde tanımlanmakta, kültürel konuların sanki eğitimle ilgili olmadığına dair bir görünüm oluşmaktadır. Oysa bu konular eğitimden dışlanmamakta, aksine Neo-liberal politikalar çerçevesinde yeniden yorumlanarak içerilmektedir (Rızvı ve Lingard, 2016, s. 96).

Eğitimin işgücüne vasıf kazandırma işlevinin son yıllara özgü olmadığını vurgulamak gerekir. Günümüzde gelişen teknolojiyle birlikte değişen işgücü niteliklerini sağlamak üzere eğitimden beklenen işlev ile 19. yüzyılda sanayileşmenin hızlanmasıyla birlikte eğitimden beklenen işlev arasında paralellik söz konusudur. Sanayileşmenin gelişmesi, uluslararası ticaretin hızlanması hesap-kitaptan anlayan, okur-yazar bir işgücü gereksinimini ortaya çıkarmıştır. Bunun yanı sıra işçilerin fabrika kurallarına uyum, dakiklik, otoriteye ve mülkiyete saygı gibi davranışları kazanması gerekli olmuştur. Hem okuryazarlı̆̆ın sağlanması hem de disiplin ve çeşitli alışkanlıkların kazandırılmasında eğitim önemli bir rol oynamıştır. Althusser'in (2006) vurguladığı gibi, çocuklar etkiye en açık olduğu çağda alınarak eğitim yoluyla sınıflı toplumlarda yerine getirmesi gereken toplumsal role uygun ideolojiyle donatılmıştır. Eğitim ve ekonomik yapı arasında benzerlik oluşturularak çocukların eğitim yoluyla toplumsal iş bölümüne ve modern işletmelerdeki iş hiyerarşisine uygun becerilerle donatılması sağlanmıştır (Bowles ve Gintis, 1976). Eğitime yönelik politikalar 19. yüzyılda önce ilkokul eğitiminin kitleselleşmesini sağlamış, ilkokul üstü eğitime olan gereksinimin artmasıyla birlikte orta 
ve yükseköğretim de küresel düzeyde genişlemeye başlamıştır. Günümüzde ise formel eğitimin yanı sıra yaşam boyu öğrenme ve diğer öğrenme biçimleriyle "dijital okuryazarlık", "girişimcilik", "esneklik", "uyumluluk" gibi özellikler kazandırılmaya çalışılmaktadır. Her iki dönemde de eğitim yoluyla çeşitli vasıfları kazandırmanın az sayıda, belirli bir kesimi değil, çok sayıda kişiyi hedeflediği, bu eksende kitleselleşmeye yönelik politikaların izlendiği görülmektedir. Oysa teknoloji-vasıf tartışmalarında da görüldüğü üzere, ileri teknolojilerin devreye girmesiyle birlikte bir yandan istihdamda azalma beklendiği gibi, diğer yandan vasıflı çalışan gereksiniminin daha az olması beklenmektedir. $\mathrm{O}$ halde neden nitelikli işgücünün artması ve küresel düzeyde genişlemesi istenmektedir? Huws'a (2006, s. 58) göre, az sayıda insan bu vasıflara sahip olduğu takdirde, işverenin manevra kabiliyetini sınırlandırabilecek, böylece bir tür pazarlık gücü sağlayacaktır. Oysa işverenler az sayıda, vasıflı, dolayısıyla güçlü işçilerle karşılaşmak, pazarlık yapmak istememektedir. İhtiyaç duydukları şey, gereksinim duyacakları vasıflardan yoksun kalmaktan korkmaksızın, ihtiyaç duyduklarında işe alacakları, ihtiyaç duymadıklarında işten çıkarabilecekleri, birbirlerinin yerine kolayca ikame edilebilir bilgisayar-okuryazarı işçilerin genişçe bir arzına sahip olmaktır (Huws, 2006, s. 58). Bu arzı garantilemenin yolu ise eğitimden geçmektedir. Dolayısıyla 19. yüzyıldaki evrensel okuryazarlık gibi, günümüz küresel kapitalizminin genelleşmiş yetenekleri kazandırmaya yönelik bir eğitim sistemine ihtiyacı vardır. Huws (2006, s. 59), 19. yüzyılda olduğu gibi günümüzde de devlet organlarının bu ihtiyaçları sağlamak üzere işverenlerin yardımına koştuğunu belirtmektedir. Aradaki tek fark, günümüzde bu durumun uluslararası örgütlerin öncülüğünde küresel düzeyde yaşanmasıdır.

Bilgi ekonomisi çağında bireylerin okullaşma süresine çok fazla odaklanılmazken, bilinmeyen ve sürekli değişen iş koşullarıyla etkili bir biçimde baş edilebilmesi için bireyin geliştirebildiği öğrenme özelliklerini önemseyen, insan kaynaklarını geliştirmeye dönük bir yaklaşım benimsenmiştir. Bu çerçevede iletişim becerileri, problem çözme, bağımsız çalışma, sürekli baskı altında kararların sorumluluğunu alma, alana özgü bilgiyi hızlı ve etkili bir şekilde elde etme yeteneği geliştirilmesi gereken beceriler arasındadır (Rızvı ve Lingard, 2016, s. 97). Ancak bilgi ekonomisi çağında edinilen becerilerin sürekli olarak kullanılabildiğini söy- 
lemek zordur. Bu nedenle öğrenme süreci sürekli olmalı ve formel eğitimle sınırlı olmamalıdır. Dolayısıyla bir yandan formel eğitim süreci hayata geçirilen reformlarla küresel düzeyde yeni işgücü niteliklerini kazandırmak üzere şekillenirken, diğer yandan bu sürecin hiçbir zaman bitmeyeceğini, değişen üretim örgütlenmesine ve teknolojiye paralel işgücünün hemen yeni duruma, yeni koşullara adapte olması gerektiğini, aksi takdirde istihdam dışı kalabileceğini salık veren yaşam boyu öğrenme yaklaşımı hızla yaygınlaşmaktadır.

\section{Yaşam Boyu Öğrenme}

Genellikle bilgi, beceri ve yeterliklerin geliştirilmesi amacıyla yaşam boyu sürdürülen tüm öğrenme etkinlikleri yaşam boyu öğrenme başlı̆̆ altında toplanmaktadır (Kaya, 2014, s. 94). Ancak bilgi ve beceri gibi kavramlara yüklenen anlamların ve bu kavramların kullanıldığı bağlamların farklılaşması yaşam boyu öğrenme tanım ve yaklaşımlarının da değişmesine yol açmaktadır. Günümüzde küresel eğitim politikalarının merkezinde yer alan yaşam boyu öğrenme yaklaşımı, mesleki olmayan öğrenme biçimlerini de kapsayacak biçimde geçen yüzyılın başlarında ortaya çıkmış; yaş, zaman ve erişim açısından sınırlandırılmayan, insanın tüm yönleriyle gelişimine imkân veren sınırsız bir öğrenme süreci olarak görülmüştür (Sayılan, 2014). 1970’li yıllarda yaşam boyu öğrenme kavramı yeniden gündeme gelmiş, eğitim ve yetiştirme politikalarını kapsayan bir anlamda kullanılmıştır. Kavramın anlamındaki asıl değişim 1990'lı yıllarla birlikte başlamıştır. Üretim örgütlenmesinde ve teknolojide yaşanan değişimlere paralel işgücü nitelikleri önemli ölçüde değişirken, bu değişimin gereklerini yerine getirecek eğitim önemli ve gerekli olmuştur. Uzunyayla ve Ercan (2008, s. 141), 20. yüzyılın son çeyreğinde eğitim politikalarının istihdam politikaları doğrultusunda; rekabeti sağlayacak, teknolojik değişimlere hızla uyum sağlayabilecek, yeni teknolojik bilgiyi hem üretecek hem de uygulayabilecek, hızlı değişimlere adapte olabilmek için öğrenmeyi öğrenecek bir işgücü yetiştirilmesi ekseninde şekillendiğini belirtmektedir. Dolayısıyla yaşam boyu öğrenme değişen işgücü niteliklerini kazandırmanın, çalışanın kendisini değişen işgücü piyasasına göre yenilemesinin bir yolu olarak görülmekte ve bu sürecin sürekliliğine vurgu yapılmaktadır. Zira modern ekonomide becerinin 
raf ömrü kısalmaktadır. Tıpkı teknolojide, bilimde ya da ileri imalat biçimlerinde olduğu gibi, işçilerin de her sekiz, on yılda bir yeniden eğitilmeleri gerekmektedir (Sennet, 2009, s. 11). Dolayısiyla güncel olan yaşam boyu öğrenme yaklaşımı neo-liberal politikalarla birlikte şekillenmiş, ekonominin gereksinimleri ekseninde tanımlanmıştır.

Son yıllarda ekonomide meydana gelen değişimler genellikle esneklik çerçevesinde ele alınmaktadır. Bu hem üretim alanının esnekliği anlamına gelirken hem de dolaşım alanında esnekliği tarif eder. Üretim alanında esneklik, yeni üretim örgütlenmesinin bir gereği olarak teknolojinin kullanılmasıyla üretimin farklı taleplere cevap verebilmesini sağlayacak biçimde düzenlenmesini ifade etmektedir. Aynı zamanda böyle hızlı değişimlere kısa zamanda uyum sağlayabilmek için firmalar çalışma koşullarını da piyasa koşullarına uygun olarak düzenlemekte, dolayısıyla esnekleştirmektedir (Demirer, 2013). Tüm bu düzenleme ve yeniden yapılanmalar çerçevesinde iş̧̧inin kazanmış olduğu bilgi ve beceriler teknolojiye dayalı yeni üretim koşullarının gereklerini karşılayamamakta, eskimektedir. Bu durumda işçinin ya yeni üretim koşullarına adapte olması, yeni üretim örgütlenmesinin gereklerini yerine getirmesi ya da iş değiştirmesi gerekmektedir. Her iki durumda da işçinin değişen iş koşullarına uygun olarak kendisini yenilemesi, yeni nitelikler kazanması kaç1nılmaz olmaktadır. Bu durumda yaşam boyu öğrenme devreye girmekte ve problemin temel çözüm kaynağı olarak tanımlanmaktadır. Bilgi ve becerilerin yalnızca ekonomi çerçevesinde tanımlanması nedeniyle yaşam boyu öğrenme, tüm felsefi ve sosyal içeriğinden soyutlanarak, iktisadi bir içeriğe hapsedilmektedir. Bu eksende alınan eğitim, bireyin özerkleşmesine ve yetkinleşmesine izin vermezken, onu piyasaya uygun niteliklerle donanmış bir işgücü olmaya hazırlamaktadır. Yaşam boyu öğrenme yaklaşımının eğitim-istihdam ilişkisi temelinde kurulması ve istihdamı sağlamak için yaşam boyu öğrenmenin bir gereklilik olarak ortaya çıması yaşam boyu öğrenme gereksinimini yerine getiremeyen bireylerin işsiz kalmalarının sorumluluğunu da kendilerine vermektedir.

Yaşam boyu öğrenmenin tarihsel gelişimi incelendiğinde, yaşam boyu eğitimden öğrenmeye doğru bir evrilme olduğu görülmektedir (Say1lan, 2014). Bu dönüşüm basit bir kelime değişiminin ötesinde anlamlara sahiptir. Öğrenme terimi, sunulan eğitim hizmetleri arasından bireyin kendi ihtiyaçlarına en uygun olanı seçip almasını gerekli kılmakta, dola- 
yısıyla söz konusu hizmete ulaşımın sorumluluğunu bireye bırakmaktadır (Kaya, 2014). Bu çerçevede yaşam boyu öğrenme başlığı altında sunulan aslında tüketici tercihine bağımlı olarak alınıp satılabilen bir tür eğitim paketine dönüşmektedir. Diğer yandan kişisel sorumluluğa bırakılması, alınan eğitimin gelecekte kar sağlayacak bir tür yatırım olarak tanımlanmasını beraberinde getirmektedir. İnsan sermayesi kuramının uzantısı olarak tanımlanabilecek bu yaklaşımda kişinin eğitime yatırım yapıp yapmaması maliyet fayda analizi yaparak iktisadi akılla verebileceği rasyonel bir karar biçimine bürünmektedir. Diğer yandan satın alınacak yaşam boyu öğrenme hizmetinin belirli bir fiyatının olması bu hizmete yalnızca parasını ödeyebilenlerin katılabilmesini mümkün kılmaktadır. Bu ise mevcut eğitim eşitsizliklerini daha fazla artırmakta, hizmet satın alma gücü olanları daha ayrıcalıklı bir konuma getirmektedir.

Yaşam boyu öğrenme yoluyla fırsat eşitliğinin formel eğitim sonrasinda da devam ettirildiği iddia edilmektedir. Zira günümüzde artan bilgi ve teknolojiye toplumun tüm kesimlerinin erişme fırsatına sahip olduğu, bu anlamda yaşam boyu öğrenmenin toplumsal eşitliğin geliştirilmesine katkı sağladığ 1 temel savlardandır. Ancak yaşam boyu öğrenmenin içeriğinin büyük oranda şirketlerin ihtiyaç duyduğu yeni nitelikler ekseninde şekillendiği göz önüne alındığında istihdam ekseninde kurgulandığ 1 fark edilmektedir. Dolayısıyla, pratikte yaşam boyu öğrenmeye küresel kapitalizm koşullarında işçilerin istihdam edilebilirlik düzeyinin ve bu yolla işletmelerin ekonomik rekabet gücünün yükseltilmesi misyonu yüklenmektedir (Güllüpınar, 2017).

\section{Sonuç}

İnsanın biyolojik bir varlık olması işgününde belirli bir süre çalışmasına olanak tanımaktadır. Dolayısıyla işçinin çalışma saatlerini uzatarak verimliliğini artırmak mümkün olsa bile bunun bir sınırı vardır. Bu nedenle çalışma süresi uzatılmadan daha fazla verim alabilmek ve dolayısıyla artı değeri artırabilmek için tek yol üretimde teknoloji kullanmaktır. Üretimde kullanılan her yeni teknoloji ile beraber hem üretim örgütlenmesinde hem de işgücü niteliğinde köklü dönüşümler yaşanmaktadır. Teknoloji ve üretim örgütlenmesinde yaşanan dönüşümlerin yeni işgücü 
nitelikleri gerektirmesi; gözlerin, bu nitelikleri kazandırmanın önemli bir yolu olarak tanımlanan eğitime çevrilmesine yol açmaktadır. Tarihsel koşullara göre farklı işlevler yüklenmekle birlikte, eğitim, sanayileşme döneminden itibaren ekonominin gereksinim duyduğu işgücü niteliklerini sağlamanın bir yolu olarak görülmüştür. Son yıllarda bu işlev küresel örgütler tarafından daha fazla dile getirilmekte, Endüstri 4.0 olarak adlandırılan yeni bir teknolojik devrim yaşandığından hareketle, eğitimin yaşanan teknolojik devrimin gereksinim duyduğu işgücü niteliklerini kazandırması gerektiği öne sürülmektedir.

1970'li yıllarda kapitalizmin krizinden bir çıkış yolu olarak uygulamaya sokulan Neo-liberal politikalar pek çok toplumsal alanda değişimler yaşanmasına yol açmıştır. Eğitimde yaşanan değişimlerin temel nedenlerinden birisinin Neo-liberal dönemde değişen işgücü niteliklerini karşılamak olduğu söylenebilir. Esneklik yeni üretim örgütlenmesinin temel sloganı olmuş, esnek üretim örgütlenmesinde yer alacak işgücünün de esnek çalışma koşullarına uyum sağlaması gerektiği öne sürülmüştür. Bu dönemde geliştirilen teknolojinin ve değişen üretim örgütlenmesinin işgücü niteliği ve istihdam üzerine etkisine ilişkin olarak temelde iki yönelimden bahsedilebilir. İlk yönelim gelişen teknolojinin, üretimde kullanılmaya başlanan otomasyon sistemlerinin işgücü niteliğini artıracağına ilişkindir. Bu yaklaşıma göre, gelişen teknolojinin bir sonucu olarak nitelikli işgücü talebi artacağı için istihdam da artacaktır. Değişen bu nitelikli işgücü talebinin karşılanabilmesi için eğitime önemli işlevler yüklenmekte yeni nitelikleri işgücüne kazandırması beklenmektedir. Bu yaklaşım aynı zamanda hizmet sektöründe yaşanan artışla birlikte mavi yakalı işgücünden beyaz yakalı işgücüne doğru bir geçiş olacağını, bir anlamda toplumun giderek profesyonellerden oluşacağını savunmaktadır. Dolayısıyla bu gelişmelere paralel yükseköğretimde de bir genişleme olması beklenmektedir. Nitekim pek çok ülkede lisans ve lisansüstü düzeyde mezunların sayısı hızla artmaktadır. Ana akım olarak tanımlayabileceğimiz bu yaklaşımların aksine diğer yönelim, yalnızca sanayi işlerinin değil, büro işlerinin de Taylorizasyona uğrayacağına, dolayısıyla bu işlerde de vasıfsızlaşma yaşanacağına ilişkindir. Gelişen teknoloji çalışanın vasıflanmasına değil, vasıfsızlaşmasına yol açacaktır. Daha az vasıflı işgücü kullanabilmek için teknolojinin daha fazla gelişmiş olması gerekmektedir. Diğer yandan gelişen teknoloji işsizliğe yol 
açacak, aynı iş daha az sayıda işgücü tarafından yerine getirilebilecektir. Eğitimde, özellikle yükseköğretimde genişleme yaşanması, ancak yükseköğretim mezunlarının istihdamını sağlayacak yeterli iş olmaması ya mezunların işsiz kalmasına yol açacak ya da daha az vasıflı işlerde çalışmalarını beraberinde getirecektir. Üçüncü bir yaklaşım ise vasıfsızlaşmanın yanında aynı zamanda yeniden vasıflanmanın da gerçekleşeceğini savunur. Bu yaklaşıma göre gelişen teknolojiyle birlikte gelişen her yeni işbölümü bir grup işçinin yeni vasıflar geliştirmesini gerekli kılarken, büyük oranda işçilerin vasıfsızlaşmasına yol açmaktadır. Dolayısıyla az sayıda vasıflı çalışanın yanında çok sayıda vasıfsız çalışan ortaya çıkmaktadır.

Endüstri 4.0 olarak adlandırılan gelişmelerle birlikte geleceğe dair kimi varsayımlarda bulunmamız olanak dâhilindedir. Robotik sistemlerin, nano teknolojinin, yapay zekânın kullanıldığı bu teknolojik dönemde hiçbir insanın çalışmadığı akıllı fabrikalardan bahsedilmektedir. Teknoloji-vasıf ve teknoloji-istihdam ilişkilerinde yukarıda bahsi geçen yaklaşımlar geçerli olmakla birlikte, insansız fabrikaların yayılmasının büyük bir kitlesel işsizlik yaratması olası görünmektedir. Makinaların insanların yerine geçeceklerine ilişkin korkunun buharla çalışan dokuma tezgâhlarının üretildiği yıllara dayandığını belirten Sennett (2009, s. 67), 19. yüzyılın sonlarına doğru insanların yaptıkları işleri makinaların yapmaya başlamasıyla birlikte çalışanların vasıfsızlaşacağının, düşük ücretli rutin işleri yapabileceklerinin öne sürüldüğünü vurgulamaktadır. Günümüzde yeni iş alanlarının açılmasına şüpheyle yaklaşılmakta ve karamsar bir tablo çizilmektedir. İnsanların işsiz kalmaması için yeni çalışma koşullarına uyum sağlaması ve gelişen teknolojiye paralel yeni beceriler edinmeleri gerektiği öne sürülmektedir. Aslında 1970'li yıllardan beri öne sürülen bu tez günümüzde yaşam boyu öğrenme yaklaşımı adı altında ifade edilmektedir. Benzer bir deneyimin 1930'ların büyük buhran yıllarında da yaşandığını belirten Sennet (2009, s. 62), insanların işsiz kalmasının nedenlerini kendilerinde aradıklarını bu nedenle işe yaramazlık hissine kapıldıklarını öne sürmektedir. Bu dönemde çocuklar istihdam edilebilmeleri için eğitim almalı ve özel beceri geliştirmeliydi. İlk bakışta her iki dönem arasında benzerlik kurmak mümkünse de, bugün işsizlikle karşı karşıya olanların çoğunun eğitimli ve vasıflı olduğunu söylemek mümkündür. Ancak mevcut eğitim sisteminin yeni işgücü 
niteliklerini karşılamada yetersiz olduğu ileri sürülerek çocuklara yine eğitim almaları gerektiği söylenmekte; kodlama, finansal okuryazarlık, elektronik tasarım öğrenmeleri önerilmektedir. Gelişen robotik teknolojilere paralel istihdamın düşmesi ve kitlesel işsizlikler yaşanması olası görünmektedir. Peki, neden israrla nitelikli işgücü talep edilmektedir? Öncelikle nitelikli işgücüne her zaman ihtiyaç duyulacak ve gelişmiş teknoloji ekseninde kimi işler daha fazla önem kazanacaktır. Ancak diğer yandan vasıf gerektiren bu işleri az sayıda kişinin yapabiliyor olması bu işlerin değer kazanmasına ve dolayısıyla işverenler için fazladan maliyete neden olacaktır. Yedek işgücü oluştuğu takdirde beklenen hedefler karşılanamadığında, vasıflı işgücü diğerleriyle kolayca ikame edilebilecektir. Bir diğer neden ise sermayenin küresel düzeyde yayılmasının küresel düzeyde nitelikli bir işgücü arzını gerekli kılmasıdır. 
EXTENDED ABSTRACT

\title{
Developing Technologies, Changing Labour Qualities and Education
}

\author{
Halil Buyruk
}

Ankara University

This paper aims to discuss the workforce qualities changing parallel to the technological advancements on the axis of the concepts of skill and employment and to reveal the reflections of these changes in the field of education. For this aim, this study first examines the historical development of technology and production organizations with the main lines, and then it discusses the changes in labour qualities in parallel with the experienced changes by a historical approach around the concepts of skill and employment. Finally, it deals with the reorganization of education in the context of previous discussions and evaluates the changes in the functions of education on the basis of knowledge economy and lifelong learning conceptualizations. Thus, it analyses the relationship between developing technologies, changing workforce qualities and education historically and theoretically.

There are basically two tendencies about the effect of developing technology and changing production organization on workforce qualities and employment. The first tendency is related to the fact that the developing technology and the automation systems which are being used in production increase the quality of the workforce. According to this approach, as a result of the developing technology, employment will also increase as qualified workforce demand increases. In order to meet this changing labour demand, it is expected that the education will have important functions and it brings new qualifications to the workforce. According to the other tendency, not only the industrial works but also the office works will also go through Taylorization, so these jobs will also be unskilled. A third tendency argues that besides deskilling, reskilling 
will also take place at the same time. According to this approach, every new division of labour developing together with the growing technology requires a group of workers to develop new qualifications; on the other hand it leads to the deskilling of most of the workers. While the function expected from education in the training of the qualified workforce needed is not changing much, the emphasis on the role of education has been strengthened in parallel with the developing technology especially in recent years.

In recent years, it has been suggested that the education should be restructured in line with the requirements of the economy both national and international level and in order to do this, regulations are made at the global level under the leadership of international organizations. The history of education's role in economy by functioning in the training of qualified labour necessary for the production goes back to the industrial revolution. The increase in mass production with industrialization created a demand for labour that would work in accordance with the newly established factory order. The workforce having workshop or home-style working habits, or from agricultural production started to learn factory layout, discipline and rules through schooling. There is a parallelism between the function expected from education with the acceleration of industrialization in the nineteenth century and the function expected from education to provide changing workforce qualities with the development of technology in recent years. Today, however, this function has a more centralized position and the educational policies shaped entirely by the economy are being accelerated. While existing change is defined as a requirement of developing technology, it is pointed out that providing these qualities by education is important because new technologies require new qualifications. It is expected that education will bring features such as "digital literacy", "entrepreneurship", "flexibility", "compatibility".

It can be said that the function of education shaped by the changing conditions of capitalism has evolved through from provision of universal literacy to broadening global computer literacy. The function of education in the new capitalism is discussed around the knowledge economy, and it is suggested that the education should be reformed in line with the requirements of knowledge economy. In the age of knowledge economy, 
an approach has been adopted to develop human resources, which emphasizes the learning characteristics that an individual can develop in order to be able to cope effectively with unknown and constantly changing working conditions, while not focusing too much on the length of schooling. In this context; communication skills, problem solving, independent study, taking responsibility for decisions under constant pressure are among the skills that need to be improved.

It is argued that a new industrial revolution has been experienced, defined by the concepts such as smart factories, internet of things, cyberphysical systems. With this revolution, it is claimed that on the one hand, the nature of work, the quality of the workforce, the organization of production will change on the other hand education must be transformed into this axis. It is argued that the current education system is insufficient to meet the new labour qualities and it is said that children need to be educated; coding, financial literacy, electronic design learning are suggested. In addition to this, bringing various qualifications through education seems to target a large number of people, not a small number of people or a certain segment. Therefore, the policies towards massification are being followed. However, as seen in the technology and skill debates, it is expected that with the introduction of advanced technologies, employment will decrease and skilled labour requirement will be less. Why then is it necessary to increase the qualified workforce and to expand it at the global level? First of all, qualified workforce will always be needed and some jobs will become more important on the basis of advanced technology. However, the fact that only a small number of people can do these jobs will require them to be valued and therefore this will lead to extra cost for employers. If the reserve workforce is created, skilled labour can easily be replaced with others when the expected targets are not met. Another reason is that the expansion of capital at the global level necessitates a qualified workforce at the global level. 


\section{Kaynakça / References}

Aksoy, S. (2017). Değişen teknolojiler ve endüstri 4.0: Endüstri 4.0'1 anlamaya dair bir giriş. Katkı, 4, 34-44.

Alçın, S. (2016). Üretim için yeni bir izlek: Sanayi 4.0. Journal of Life Economics, 8, 19-30, Doi: http://dx.doi.org/10.15637/jlecon.129.

Althusser, L. (2006). İdeoloji ve devletin ideolojik aygıtları (Çev. A. Tümertekin). İstanbul: İthaki Yayınları.

Amin, A. (2003). Post-Fordism: models, fantasies, and phantoms of transition. A. Amir (Der.), Post Fordism A Reader (ss.1-40), Oxford UK: Blackwell.

Ansal, H. (1996a). Esnek üretimde işçiler ve sendikalar. İstabul: Birleşik Metal-iş Sendikası Yayınları.

Ansal, H. (1996b). Teknolojik gelişmelerin işgücü niteliğine etkileri. Lordoğlu, K.(Ed.), Insan, Toplum, Bilim, Ulusal Sosyal Bilimler Kongresi Bildiriler Kitabı, İstabul: Kavram Yayınları.

Apple, M. W. (2006). Egitim ve iktidar (Çev. Ergin Bulut). İstanbul: Kalkedon Yayınları.

Autor, D. H., Levy, F. and Murnane, R.J.(2003). The Skill content of recent technological change: An empirical exploration. Quarterly Journal of Economics, 118 (4): 1279-1333.

Aydoğanoğlu, E. (2011). Fabrikada emek denetimi. İstanbul: Evrensel Basım Yayin.

Becker, G. S. (1964). Human capital: A Theoretical and empirical analysis, with special reference to education. New York: National Bureau of Economic Research.

Bell, D. (1999). The coming of post industrial society. USA: Basic Books.

Belek, İ. (1997). Postkapitalist paradigmalar. İstanbul: Sorun Yayınları.

Braverman, H. (2008). Emek ve tekelci sermaye (Çev. Ç. Çidamlı). İstanbul: Kalkedon Yayınları.

Bowles, S. \& Gintis H. (1976). Schooling in capitalist america: educational reform and the contradictions of economic life. New York: Basic Books.

Buyruk, H. (2013) Türkiye'de öğretmen emeğinin tarihsel dönüşümüne ilişkin ekonomi-politik bir çözümleme. Yayımlanmamış doktora tezi, Ankara Üniversitesi Eğitim Bilimleri Enstitüsü, Ankara. 
Çakmak, U. (2004). Esnek üretim sistemi: istihdama etkisi ve toyota örneği. Ekonomik Yaklaşım, 15(52- 53), 235-253.

Demirer, D. K. (2013). Eğitim, bilgi ekonomisi ve istihdam. Praksis, 33(3), 49-61.

Dickson, D. (1992). Alternatif teknoloji (Çev. N. Erdoğan). İstanbul: AyrıntıYayınları.

DPT (2006). Kalkınma planı, dokuzuncu beş yıl, 2007-2013, Ankara.

Drucker, P. F. (1993). Yeni gerçekler (Çev. B. Karanakçı). Ankara: Türkiye İş Bankası Yayınları.

Drucker, P. F. (1994). Kapitalist ötesi toplum (Çev. B. Çorakçı). İstanbul: İnkılâp Yayınları.

Frey, c. B. \& Osborn, M. A. (2017). The future of employment: How susceptible are jobs to computerisation? Technological Forecasting $\mathcal{E}$ Social Change, 114, 254-280.

Friedman, A. L. (1977). Responsible autonomy versus direct control over the labour process. Capital and Class, 1(1), 43-57.

Giddens, A. (2008). Sosyoloji. İstanbul: Kırmızı Yayınları.

Green, A. (1990). Education and state formation. The rise of education systems in England, France and the USA, London: Macmillan.

Güllüpınar, F. (2017). Kamusallığın çöküşü ve bireyin sorumlulaştırılmas1 olarak 'yaşam boyu öğrenme': Eğitim ve istihdam politikalar1nın eleştirisine bir katkı. Amme İdaresi Dergisi, 50(1), 67-84.

Harvey, D. (1999). Postmodernliğin durumu (Çev. Sungur Savran). İstanbul: Metis Yayınları

Hirsch, J. (2011). Materyalist devlet teorisi (Çev. L. Bakaç). İstanbul: Alan Yayıncllik

Huberman, L. (2009). Feodal toplumdan yirminci yüzyıla. İstanbul: İletişim Yayınlar1

Huws, U. (2006). Ne iş yapacağız? "Bilgi-temelli ekonomi" de meslekî kimliklerin yıkımı. Monthly Review Dergisi, 2, 47-63.

Kaya, H. E. (2014). Küreselleşme sürecinde yaşam boyu öğrenme ve yetişkin eğitimi gerçeği. Akademik İncelemeler Dergisi, 9(2), 91-111.

Keynes, J. M. (2008). Genel teori - istihdam, faiz ve paranın genel teorisi (çev. U. S. Akalın). İstanbul: Kalkedon.

KB (Kalkınma Bakanlığı) (2013). Kalkınma planı, Onuncu beş yıl, 20142018, Ankara: KB. 
Kumar, K. (2004). Sanayi sonrası toplumdan post-modern topluma: Çă̆daş dünyanın yeni kuramları. Ankara: Dost Kitabevi Yayınları.

Lauder, H., Young, M., Daniels, H., Balarin, M., Lowe, J. (2012). Introduction: Educating for the knowledge economy?: Critical perspectives. In H. Lauder, M. Young, H. Daniels, M. Balarin, J. Lowe (Eds.) Educating for the knowledge economy?: Critical perspectives. London and Newyork.: Routledge.

Machin, D. (2003), The changing nature of labor demand in the new economy and skill-biased technology change. Oxford Bulletin of Economics and Statistics, 63-S, 753-776.

Marx, K. (2011). Kapital Cilt 1(Çev. Nail Satligan). İstanbul: Yordam Kitap.

OECD (1996). The Knowledge-based economy. Paris: OECD.

OECD (2013), Trends shaping education 2013. OECD Publishing. http://dx.doi.org/10.1787/trends_edu-2013-en

OECD (2015). OECD Skills outlook 2015: Youth, skills and employability. OECD Publishing. http://dx.doi.org/10.1787/9789264234178-en.

Piore, M. ve Sabel, C. (1984), The second industrial divide: Possibilities for prosperity. New York: Basic Books.

Rızvı, R. \& Lingard, B. (2016). Küreselleşen eğitim politikası (Çev. B. Balkar, H. Özgan). Ankara: Pegem Akademi

Rifkin, J. (1995), The end of work - The decline of the global labor force and the dawn of the post-market era. New York: Tarcher/Putnam.

Rury, J. L. (2002). Education and social change: Themes in the history of american schooling. Mahwah, New Jersey: Lawrence Erlbaum Associates, Inc.

Sayers, S. (2008). Marksizm ve insan doğası (Çev. Ş. Alpagut). İstanbul: Yordam Kitap.

Sayılan, F. (2014). Some critical reflections on lifelong learning policy in Turkey. Journal for Critical Education Policy Studies, 12(3), 156-170.

Sennett, R. (2005). Karakter aşınması (Çev. B. Yıldırım). İstanbul: Ayrıntı Yayınları.

Sennett, R. (2009). Yeni kapitalizmin kültürü (Çev. A. Onacak). İstanbul: Ayrıntı Yayınları.

Schultz T W (1961). Investment in human capital. The American Economic Review, 51(1), 1-17. 
Taylor, F. W. (2011). Bilimsel yönetimin ilkeleri (Çev. H. B. Akın). Ankara: Adres Yayınları.

Thompson, P. and Smith, C. (2009). Labour power and labour process: Contesting the marginality of the sociology of work. Sociology, 43(5), 913-930.

Toffler, A. (2008). Üçüncü dalga: Bir fütürist ekonomi analizi klasiği (Çev. S. Yeniçeri). İstanbul: Koridor Yayıncıllk.

Tokol, A. (2000). Yeni teknolojiler ve değişen endüstri ilişkileri. İş Güç Endüstri İlişkileri Dergisi, 2(1), 1-13.

TÜSİAD (2006). Eğitim ve sürdürülebilir büyüme. Türkiye deneyimi, fırsatlar ve riskler. İstanbul. Lebib Yalkın Yayımları.

Uzunyayla, F. \& Ercan, F. (2008). Türkiye'de eğitim sistemine yönelik yeni talepler ve yeni aktörlere sınıfsal bir bakış. S. Akyol, M.K. Coşkun, Z. Yılmaz, M.B. Aydın, R. Altunpolat (Der.), Dönüştürülen üniversiteler ve eğitim sistemimiz. Ankara: Eğitim Sen Yayınları.

Ünal, L. I. (1996). Eğitim ve yetiştirme ekonomisi. Ankara: Epar Yayınları

Vivarelli, M. (2007), Innovation and Employment: A Survey, IZA Discussion paper, No. 2621.

Vivarelli, M. and Pianta, M. 2000 (eds.), The Employment impact of innovation: Evidence and Policy. London: Routledge.

World Bank (2005). Education sector strategy update: Achieving education for all, Broadening our perspective, maximizing our effectiveness. http://siteresources.worldbank.org/EDUCATION/ Resources/ESSU/Education_Sector_Strategy_Update.pdf

Yentürk, N. (1993). Post-Fordist gelişmeler ve dünya iktisadî işbölümünün geleceği. Toplum ve Bilim. Bahar, 42-56.

\section{Kaynakça Bilgisi / Citation Information}

Buyruk, H. (2018). Gelişen teknolojiler, değişen işgücü nitelikleri ve eğitim. OPUS - Uluslararası Toplum Araştırmaları Dergisi, 8(14), 599632. DOI: $10.26466 /$ opus. 404223 